\title{
Reciprocity between agricultural management and productivity in Nawalparasi district
}

\author{
Bhola Nath Dhakal \\ Ratna Rajyalaxmi Campus, Tribhuvan University, Kathmandu \\ Email: dhakalbn@gmail.com
}

\begin{abstract}
Farm management is the making, organizing and operating a farm through the appropriate and timely inputs for maximum production and profit. This paper seeks to explore farm land management practices in-terms of input use in three different sites: Jahada, Palhi and Ramnagar of Nawalparasi district. The paper is based on collected primary data through household questionnaire survey, Focus Group Discussion (FGD), Key Informant Interview (KII) and field observation methods. Secondary sources of data through topographic and cadastral maps have also been used in this study. Use of different types of labour force, increasing the input use of manure, chemical fertilizers and pesticides, use of modern machineries, development of irrigation facilities, land intensification and crop diversification are the major strategies for agricultural development adopted by local peoples in the study sites.
\end{abstract}

DOI: http://dx.doi.org/10.3126/gjn.v12i1.23419

Keywords: land management, agricultural labour force, land intensification, crop diversification

\section{Introduction}

Land resource management helps to promote economic and social development in both urban and rural areas. Kristensen (1999) has found agricultural land management through the process of intensification and extensification in Rostrup, Denmark. Sen et al. (2002) have found agricultural practices by increased in use of manure input by 50 percent in Pranmati watershed in Indian Himalaya. Carswell (2002) has found farmers have managed their land and maintained productivity by adding manure, fertilizers and 
machinery use in the area of Kigezi, Uganda. Semwal et al. (2004) have found the changes in spatial patterns of agricultural land use through crop diversification, increased manure input for high yield, managed soil loss and run-off from cropland in a small watershed in Central Himalaya, India. MacLeod \& Moller (2006) have identified agricultural development practices through conversion to more intensive forms of agriculture, and diversification of crops, increased farm fertilizer and pesticide inputs in New Zealand. Wu et al. (2009) have found agricultural development strategies through intensification (changing in cropping pattern from two crops to three/four crops, inter-cropping) of land in Yixing, China. Burgess \& Morris (2009) have explored that farmer using agricultural machineries (tractors and thresher), hybrid seeds and chemical fertilizers to increase the output of crop and animal products per unit of land in the United Kingdom. Thapa \& Yila (2012) have found application of chemical fertilizers and farm yard manure, intercropping and crop rotation as major agricultural development practices in Jos Plateau in Nigeria. Bhat (2013) has assessed the agricultural land use at micro level in Pulwama district of Kashmir Valley and found that the horizontal expansion of agriculture and utilization of land by adopting more remunerative cropping pattern, scientific rotation of crops and multiple cropping patterns to have helped in growing more food and raw material problems in the region. Miheretu \& Yimer (2017) have found that adoption of mixed cropping, crop rotation, use of manure and chemical fertilizer for the agricultural land management in Ethiopia.

Poudel (2002) has found that farmers have intensified land use and cultivated new crops to increase farm production and income in the Western Hills of Nepal. There was a constant shifting from cereal crops to livestock husbandry, particularly along the road, vegetables and other cash crops in the accessible foothills. Khanal (2002) has noticed change on the use of manure, chemical fertilizers, and high yield varieties of seeds and irrigation for increase production level of different crops in Mid-Hills of Nepal. Dahal et al.(2009) have found that intensification of land by input use of chemical fertilizers, pesticides, high yield varieties of seeds and use of machineries as an important strategy in agricultural commercialization and uplifting economic conditions of rural farmers of Nepal. Nepal \& Thapa (2009) have noticed that the use of inputs such as manure, chemical fertilizers, pesticides, farm machines, including tractors and pump-sets, help farmers cope with complexity of agricultural development in Morang district of Nepal. Farmers have used higher quantity of agriculture inputs such as fertilizer, hybrid seeds, insecticides, pesticides as well as modern agriculture tools such as tractor, power tillers, and threshers and development of irrigation facilities in the cropping area in Kanchanpur district of Nepal (Paudyal, 2010).The use of inputs like modern farm technologies, such as tractors, chemical fertilizers, irrigation and hybrid seeds are also increasing for agricultural development in Chitwan (Adhikari, 2013; Bhandari and Ghimire, 2013 cited in Bhandari and Ghimire, 2016). 
Agricultural land management refers to practices and use of technologies making land optimum use that aims to meet human needs. It is obvious that the processes and state of input use in land management are very complex with space and time. In this context, the present paper seeks to explore agricultural land management practices of the farmers living within three different sites of Nawalparasi district

\section{Conceptual framework and methods}

Based on the review of literature a research framework has been designed (Figure 1). Firstly, the types and trend of input use by farmers was assessed; secondly the processes to develop such trend were identified and lastly the output was assessed based on the level of input use and level of production through the productivity and monetary value.

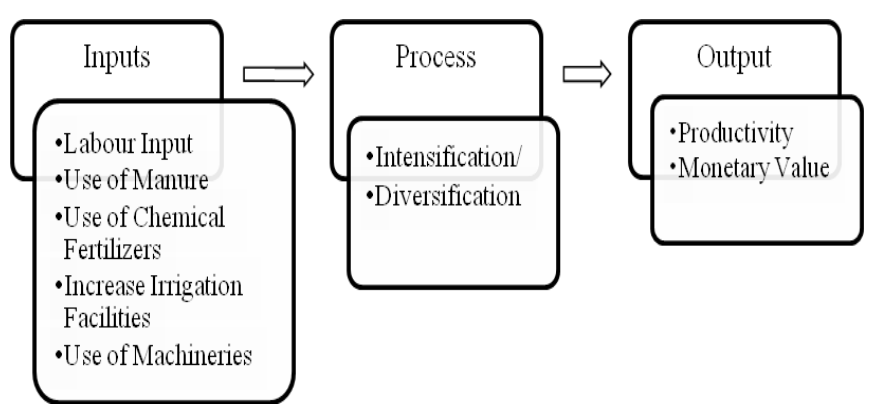

Figure 1: Conceptual framework of the study

The present study has used both primary and secondary data. Primary data has been generated from household survey. All together 93 households ( 31 households from each site) were surveyed with semi structured questionnaire. Information on land management practices by the farmers was collected through face to face household questionnaire survey. Focus Group Discussion and Key Informant Interview was conducted for firsthand knowledge about the community and agricultural activities. Field observation has been conducted for identification of parcels and different management practices (intensification/diversification) on cadastral and topographic maps. Parcels were identified through the provided land registration certificates (lalpurja) by farmers in the field and verification has been carried out in district land revenue office. However, all the parcels were not identified on the map as well as on the ground due to the unavailability of certificates and hesitation on sharing by farmers. Similarly, the available secondary data and reports such as VDC profiles, annual progress reports, published articles, maps and images has been used to create secondary data. Both qualitative and quantitative techniques have been used for the data generation and compilation. 


\section{Study area}

Nawalparasi district (Bardaghat-Susta West) is located in Province number 5 of Nepal. Ecologically, it lies in the Tarai region bordering Palpa district in the north, Nawalparasi (Bardaghat-Susta East) and Chitwan districts in the east, Bihar (India) in the south, and Rupandehi in the west. During the period of field work, the district was divided into 56 VDCs, 7 Municipalities, 15 Ilakas and 6 Constituencies (MoFALD, 2015). Out of these, three VDCs (Jahada, Palhi and Ramnagar) are selected for detail field survey based on biophysical and socio-economic characteristics. Ward number 3 of Jahada VDC (here after Jahada), ward number 9 of Palhi VDC (here after Palhi) and ward number 5 of Ramnagar VDC (hereafter Ramnagar) were selected randomly for detail study (Figure 2).

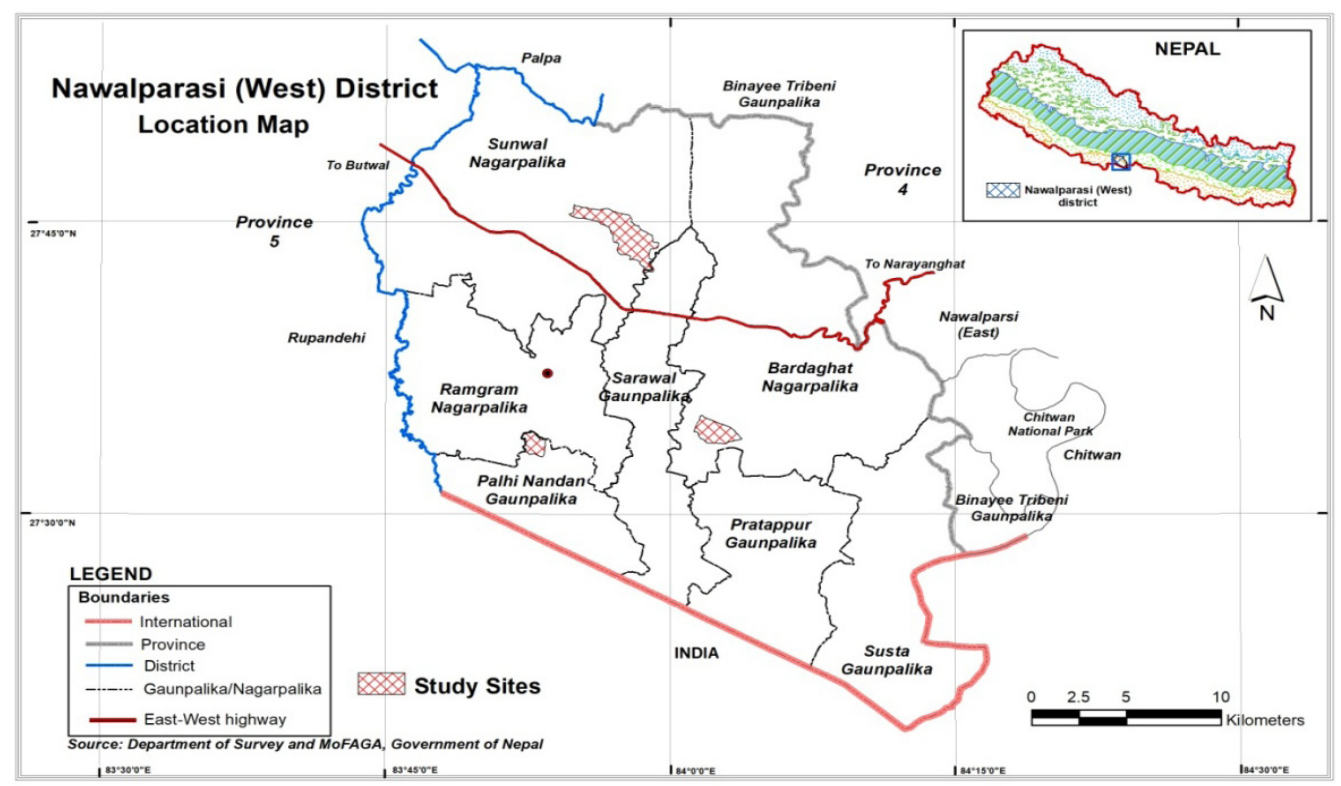

Figure 2: Location of study sites

\section{Results and discussions}

The agronomic land management practices have been observed in the study area. These practices include use of labour force and machineries, use of manure, improved seeds, chemical fertilizers, pesticides and irrigation, land intensification and crop diversification. 


\section{Use of labour and machineries}

The variation has been found in labour use by land holding size in all study sites. Labour input has increased in major crops such as, potato, wheat, pulses and oil seeds by different sizes of land holdings (Dhakal, 2018). It has happened due to farmers prioritized in cash crop cultivation with the development of road access and market centers. The labour input is higher in small size of land holding in major crops such as paddy and wheat cultivation in all study sites due to insufficient farm size for machinery use. Farmers have utilized hired and exchanged labours in addition to own family labours during the planting, weeding and harvesting time. In addition, they have been using modern machineries like tractors and threshers in major crops (Table 1) such as paddy, wheat and pulse cultivation to manage land in the absence or lacking of labour during the plantation and harvesting period in the study sites. The using trend of machineries has also been increased in all study sites.

Table 1: Use of machineries (in percent)

\begin{tabular}{|l|r|r|r|r|}
\hline \multirow{2}{*}{ Study sites } & \multicolumn{2}{|c|}{ Tractors } & \multicolumn{2}{c|}{ Threshers } \\
\cline { 2 - 5 } & $2005 / 06$ & $2015 / 16$ & $2005 / 06$ & \multicolumn{1}{c|}{$2015 / 16$} \\
\hline Jahada & 61.3 & 90.3 & 38.7 & 64.5 \\
\hline Palhi & 71.0 & 87.1 & 48.4 & 83.9 \\
\hline Ramnagar & 74.2 & 96.8 & 41.9 & 93.5 \\
\hline Total & 68.8 & 91.4 & 43.0 & 80.6 \\
\hline
\end{tabular}

Source: Field survey, 2015/16

There are different types of labour input practices observed in study sites. Among them, family labours are higher in Palhi than Jahada and Ramnagar because of large family size and availability of working age group of family members. Whereas, hired labour are higher in Jahada and Ramnagar due to scarcity of agricultural labour force. Moreover, the practice of exchange labour system is also found in Jahada and Ramnagar particularly in paddy, wheat and potato cultivation (Table 2). 
Table 2: Family size and use of labour by types (in percent)

\begin{tabular}{|l|l|r|r|r|}
\hline \multicolumn{1}{|c|}{ Characteristics } & \multicolumn{1}{|c|}{ Categories } & \multicolumn{1}{c|}{ Jahada } & Palhi & Ramnagar \\
\hline Working Age Group & 15-59 years & 60.2 & 68.4 & 63.5 \\
\hline \multirow{2}{*}{ Family Size } & Equal to and less than 5 & 35.5 & 19.4 & 25.8 \\
\cline { 2 - 5 } & Greater than 5 & 64.5 & 80.6 & 74.2 \\
\hline \multirow{3}{*}{ Types of labour } & Family members & 27.1 & 59.8 & 28.8 \\
\cline { 2 - 5 } & Hired labour & 59.6 & 39.6 & 60.1 \\
\cline { 2 - 5 } & Exchange labour & 13.3 & 0.6 & 11.1 \\
\hline
\end{tabular}

Source: Field survey, 2015/16

The study has found the variation on labour input and output intensity by crops and study sites. Labour input intensity is the highest in potato cultivation in Jahada (81 persons/ha) and Palhi (70 persons/ha) followed by paddy cultivation (Dhakal, 2018). Furthermore, labour input intensity is the highest in paddy cultivation in Ramnagar (95 persons/ha) followed by potato cultivation. However, the highest productivity is found in paddy (7511 $\mathrm{kg} / \mathrm{ha}$ in Palhi, $6494 \mathrm{~kg} / \mathrm{ha}$ in Jahada and $6153 \mathrm{~kg} / \mathrm{ha}$ in Ramnagar) followed by potato in all study sites. In addition, the highest output intensity is found from paddy production in all study sites followed by potato in Jahada and Ramnagar and by vegetables in Palhi.

\section{Use of manure}

The use of manure input in paddy cultivation has increased in all study sites even in different sizes of land holdings. However, the use of manure in paddy cultivation has been decreased in small size (less than 0.5 ha) of holdings than larger size in Palhi (Table 3). Participants during FGD reported that farmers have used maximum quantity of manure in small size of land holdings in Jahada and Ramnagar, however farmers have used less quantity of manure in small size of land holdings in Palhi. After the discussion on issues of manure input and situation of production trend, KIs informed that they have faced the effect of diseases like daduwa (sheath blight), patera (rice bug) and gobaro (borer) to have damaged the potato and paddy crops in Palhi and Jahadalast year due to the use of chemical fertilizers.

Table 3: Utilization of manure $(\mathrm{kg} / \mathrm{ha})$ by land holdings size in paddy

\begin{tabular}{|l|r|r|r|r|r|r|}
\hline \multirow{2}{*}{$\begin{array}{l}\text { Size of land } \\
\text { holding (ha) }\end{array}$} & \multicolumn{2}{|l|}{ Jahada } & \multicolumn{2}{l|}{ Palhi } & \multicolumn{2}{l|}{ Ramnagar } \\
\cline { 2 - 7 } & $2005 / 06$ & $2015 / 16$ & $2005 / 06$ & $2015 / 16$ & $2005 / 06$ & \multicolumn{2}{l|}{$2015 / 16$} \\
\hline Less than 0.5 & 6728 & 8644 & 1897 & 1761 & 4239 & 4663 \\
\hline 0.5 to 1.0 & 2935 & 3625 & 2071 & 2390 & 3574 & 3724 \\
\hline 1.1 to 1.5 & 986 & 1409 & 1644 & 2560 & NA & NA \\
\hline More than 1.5 & 4994 & 6657 & 1942 & 2157 & NA & NA \\
\hline
\end{tabular}

Source: Field survey, 2015/16

(NA:Not Applicable)

(NA: Ramnagar does not have available land holdings size of more than 1 hectare) 
This study found use of manure is higher in paddy cultivation in all the study sites than district average $(1042 \mathrm{~kg} / \mathrm{ha})$ and national average $(1190 \mathrm{~kg} / \mathrm{ha})(\mathrm{MoAD}, 2016)$. It shows that farmers have given emphasis to use high input of manure in paddy cultivation.

\section{Use of chemical fertilizers}

Chemical fertilizer has been used in paddy, wheat and oil seeds in all study sites. The trend of chemical fertilizer use has increased in all crops by different size of land holdings in Jahada and Ramnagar. However, it has been decreased in paddy cultivation under small land holdings sizes (less than 0.5 ha) in Palhi due to inputs of manure is higher in small size of holdings (Table 4). The result shows that the average uses of chemical fertilizers in paddy and wheat which is higher than district and national level in all study sites. It is recorded $90 \mathrm{~kg} / \mathrm{ha}$ in district level and $126 \mathrm{~kg} / \mathrm{ha}$ in an average in national level in paddy and $150 \mathrm{~kg} / \mathrm{ha}$ in district level and $104 \mathrm{~kg} / \mathrm{ha}$ in average in national level in wheat cultivation during the same study year (MoAD, 2016).

Table 4: Use of fertilizers ( $\mathrm{kg} / \mathrm{ha})$ by land holding size and crops

\begin{tabular}{|c|l|r|r|r|r|r|r|}
\hline \multirow{3}{*}{ Crops } & \multicolumn{1}{|c|}{$\begin{array}{c}\text { Size of land } \\
\text { holding (ha) }\end{array}$} & \multicolumn{2}{|c|}{ Jahada } & \multicolumn{2}{|c|}{ Palhi } & \multicolumn{2}{c|}{ Ramnagar } \\
\cline { 3 - 8 } & & $2005 / 06$ & $2015 / 16$ & $2005 / 06$ & $2015 / 16$ & $2005 / 06$ & $2015 / 16$ \\
\hline \multirow{5}{*}{ Paddy } & Less than 0.5 & 136 & 169 & 338 & 313 & 102 & 112 \\
\cline { 2 - 8 } & 0.5 to 1.0 & 118 & 163 & 207 & 239 & 75 & 78 \\
\cline { 2 - 8 } & 1.1 to 1.5 & 54 & 77 & 194 & 230 & NA & NA \\
\cline { 2 - 8 } & More than 1.5 & 160 & 266 & 237 & 263 & NA & NA \\
\hline \multirow{5}{*}{ Wheat } & Less than 0.5 & 129 & 150 & 369 & 428 & 118 & 190 \\
\cline { 2 - 8 } & 0.5 to 1.0 & NA & NA & 247 & 290 & NA & NA \\
\cline { 2 - 8 } & 1.1 to 1.5 & NA & NA & 102 & 141 & NA & NA \\
\cline { 2 - 8 } & More than 1.5 & 266 & 289 & 360 & 254 & NA & NA \\
\hline \multirow{3}{*}{ Oilseeds } & Less than 0.5 & 21 & 29 & 44 & 69 & 11 & 7 \\
\cline { 2 - 8 } & 0.5 to 1.0 & 15 & 21 & 23 & 19 & NA & NA \\
\hline
\end{tabular}

Source: Field survey, 2015/16

(NA:Not Applicable)

\section{Use of pesticides}

Farmers use pesticides only in paddy cultivation. It is found that use of pesticides has been increased in paddy in different sizes of land holdings in all study sites. Furthermore, it has been noticed that the use of pesticides is higher in small size of land holdings than large size in Jahada and Palhi, but it is increased by land holding size in Ramnagar (Table 5). 
Table 5: Use of pesticides ( $\mathrm{ml} / \mathrm{ha}$ ) in paddy by land holdings size

\begin{tabular}{|l|r|r|r|r|r|r|}
\hline \multirow{2}{*}{$\begin{array}{l}\text { Size of land } \\
\text { holding (ha) }\end{array}$} & \multicolumn{3}{|l|}{ Jahada } & \multicolumn{2}{l|}{ Palhi } & \multicolumn{2}{l|}{ Ramnagar } \\
\cline { 2 - 7 } & $2005 / 06$ & $2015 / 16$ & $2005 / 06$ & $2015 / 16$ & $2005 / 06$ & \multicolumn{1}{l|}{$2015 / 16$} \\
\hline Less than 0.5 & 80 & 92 & 379 & 352 & 26 & 46 \\
\hline 0.5 to 1.0 & 56 & 69 & 256 & 296 & 407 & 424 \\
\hline 1.1 to 1.5 & 49 & 60 & 173 & 180 & NA & NA \\
\hline More than 1.5 & NA & NA & 129 & 144 & NA & NA \\
\hline
\end{tabular}

Source: Field survey, 2015/16

(NA:Not Applicable)

The use of pesticides is more than district average $(370 \mathrm{ml} / \mathrm{ha})$ and national average (391 $\mathrm{ml} / \mathrm{ha}$ ) in Palhi and Ramnagar but less than in Jahada with the average during the same study year (MoAD, 2016). However, respondents during FGD and KII informed that they have not given more priority to use chemical fertilizers. They are reported to have discussed for other alternates of chemical fertilizers before use.

\section{Irrigation and crop productivity}

Irrigation is an important factor in agricultural development. Productivity depends mainly on the availability of irrigation facilities on the one hand and the varieties of seeds on the other. The total of 22.6 percent of respondents from Jahada, 35.5 percent of respondents from Palhi and 16.1 percent of respondents from Ramnagar (Figure 3) reported that development of irrigation facilities have contributed to the management on agricultural land. Development of swallow and deep tube wells in Jahada, maintenance of old canal and water for irrigation in Palhi and construction of irrigation ditch (kulo) have contributed in providing irrigation facilities in Ramnagar. This has greatly encouraged farmers for multi cropping during an agricultural year. It has also resulted high yield in crops. Whereas 21.4 percent of respondents noticed that lack of irrigation facilities, insufficient water supply on existing canals and untimely weather condition caused decreasing production of crop. The cultivated area with irrigation facilities has increased in all study sites during the study period. Altogether 12 percent of the total crop land has been increased irrigation facilities during the study period. It has been increased by 13.6 percent in Jahada, 11.4 percent in Palhi and 11 percent in Ramnagar (Table 6). 


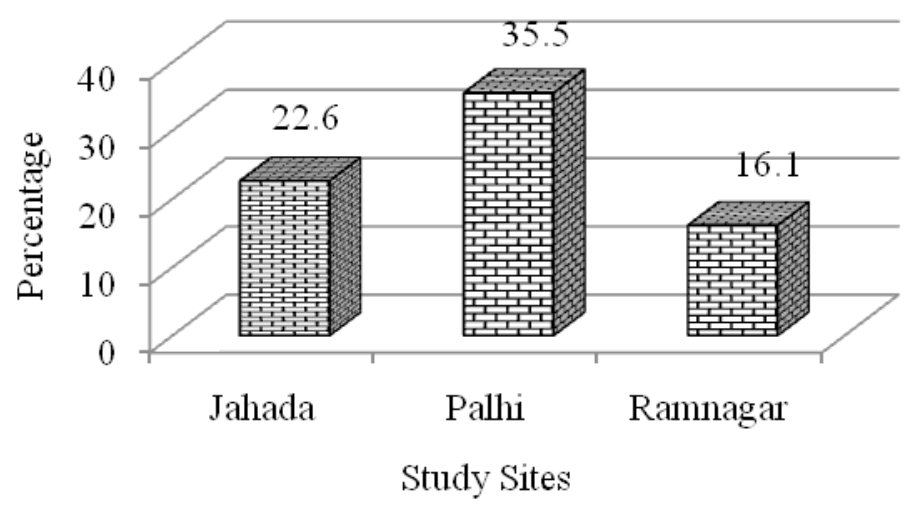

Figure 3: Impact of irrigation on agriculture development

Table 6: Change in irrigation facilities (area in hectare)

\begin{tabular}{|l|c|r|r|r|r|}
\hline \multirow{2}{*}{ Study sites } & \multicolumn{2}{|l|}{$2005 / 06$} & \multicolumn{2}{l|}{$2015 / 16$} & \multirow{2}{*}{$\begin{array}{l}\text { Change in } \\
\text { percent }\end{array}$} \\
\cline { 2 - 6 } & Area & Percent & Area & Percent & 13.6 \\
\hline Jahada & 17.988 & 49.3 & 17.986 & 62.9 & 11.4 \\
\hline Palhi & 40.488 & 68.1 & 32.353 & 79.5 & 11.0 \\
\hline Ramnagar & 12.260 & 74.4 & 12.253 & 85.4 & 12.0 \\
\hline Total & 70.736 & 63.9 & 62.592 & 75.9 & \\
\hline
\end{tabular}

Source: Field survey, 2015/16

\section{Variety of seeds and productivity}

The variation on productivity of crop also depends on the use of varieties of seeds. This plays an important role in the agricultural development. Variation is seen in productivity of paddy by land holdings size with the use of varieties of seeds in the study area. The productivity of paddy has increased by 17.3 percent in the area where improved seeds were used. However, the productivity of paddy has been decreased by 6.1 percent in the area where local seeds are used in Jahada. In addition, the productivity has been increased by 57.8 percent in large size of land holding (more than 1.5 ha). The productivity of paddy has increased by 11.1 percent in the area where improved seeds were used but it has been increased only by 4.1 percent in the area where local seeds were used in Palhi. Variation is seen in productivity by land holding size. The changing trend is higher in medium size of land holdings. Furthermore, the result shows the productivity of paddy has increased from large size to small size of land holdings in Palhi. The result shows 
the productivity of paddy has been increased in both condition of area where the local and improved seeds were used in Ramnagar. Further more, it is found that productivity of paddy has been increased by 30.4 percent in the are as where the improved seeds were used. But it has been increased by 18.0 percent only in are as where the local seeds were used in Ramnagar (Table 7). In addition, the productivity of paddy is higher in medium size of land holdings as compared to other farming conditions (Dhakal, 2018).

Table 7: Change in crop productivity ( $\mathrm{kg} / \mathrm{ha}$ ) of paddy with varieties of seeds

\begin{tabular}{|l|r|r|r|r|r|r|}
\hline \multirow{2}{*}{ Study Sites } & \multicolumn{3}{|c|}{ Local Seed } & \multicolumn{3}{|c|}{ Improved Seed } \\
\cline { 2 - 8 } & $2005 / 06$ & $2015 / 16$ & $\begin{array}{c}\text { Change in } \\
\text { percent }\end{array}$ & $2005 / 06$ & $2015 / 16$ & $\begin{array}{c}\text { Change } \\
\text { in } \\
\text { percent }\end{array}$ \\
\hline Jahada & 5025 & 4721 & -6.1 & 5505 & 6456 & 17.3 \\
\hline Palhi & 4908 & 5111 & 4.1 & 7690 & 8547 & 11.1 \\
\hline Ramnagar & 3787 & 4467 & 18.0 & 5422 & 7070 & 30.4 \\
\hline
\end{tabular}

Source: Field survey, 2015/16

The research finds through the enumerated data that productivity of paddy increased in both condition of areas where local and improved seeds were used in Palhi and Ramnagar, but it has been decreased in the area where local seeds were used in Jahada due to insufficient water availability in time and comparatively poor irrigation facilities.

\section{Land Intensification}

Farmers have adopted land intensification practices in the study sites to increase agricultural production. Farmers have practiced to cultivate more crops than in the past to increase production even in the same area of land. Further, the respondents informed that 16.1 percent of agricultural land holdings used to grow three and more crops during agriculture year in Jahada, which was only11.8 percent before 10 years. Similarly, 48.4 percent of holdings are reported to grow three and more crops during agriculture year in Ramnagar now which was only 13.6 percent during 2005/06. Whereas 16.5 percent of land holdings are reported to grow three and more crops during agriculture year in Palhi, which was only 3.7 percent area of total cultivated land during 2005/06 (Figure 4). The participants during FGD and KII also further reported that farmers have tried to explore new varieties of seeds from neighboring districts and applied within two to three years' interval. Sometimes they used to repeat their own local seeds. They depended on the season and availability of irrigation facilities as well as other modern inputs like machineries, organic and chemical fertilizers, pesticides etc. 


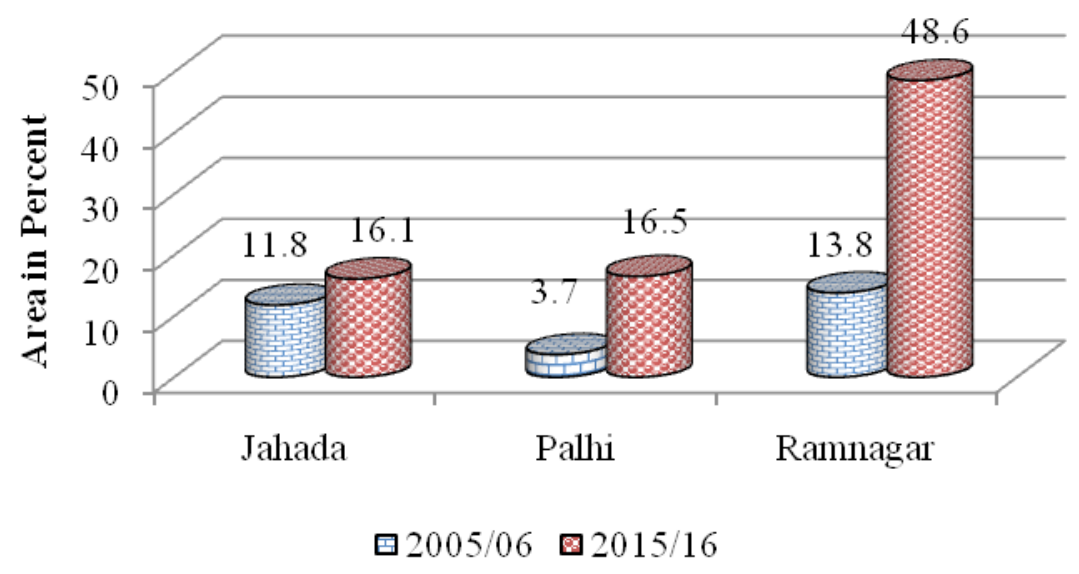

Figure 4: Trend of land intensification

Altogether 28.4 percent of total respondents within 58.8 percent of identified parcel area (44.9 percent in Jahada, 49.8 percent in Palhi and 24.7 percent in Ramnagar) have used more intensive farming in the parcels close to residence/house than some farther location (Table 8).

Table 8: Crop intensification/diversification conditions by parcels (area in ha)

\begin{tabular}{|c|c|c|c|c|c|c|c|c|}
\hline $\begin{array}{l}\text { Study } \\
\text { sites }\end{array}$ & $\begin{array}{c}\text { Total } \\
\text { parcels }\end{array}$ & Area & $\begin{array}{l}\text { Identified } \\
\text { parcels }\end{array}$ & Area & $\begin{array}{c}\text { Intensified* } \\
\text { parcels }\end{array}$ & Area & $\begin{array}{c}\text { Diversified }^{* *} \\
\text { parcels }\end{array}$ & Area \\
\hline Jahada & 59 & 28.60 & $\begin{array}{r}37 \\
(62.7)\end{array}$ & $\begin{array}{r}21.4 \\
(74.8)\end{array}$ & $\begin{array}{r}13 \\
(35.1)\end{array}$ & $\begin{array}{r}9.61 \\
(44.9)\end{array}$ & $\begin{array}{r}5 \\
(13.5)\end{array}$ & $\begin{array}{r}3.31 \\
(15.5)\end{array}$ \\
\hline Palhi & 76 & 40.70 & $\begin{array}{r}42 \\
(55.3)\end{array}$ & $\begin{array}{r}17.5 \\
(43.0)\end{array}$ & $\begin{array}{r}14 \\
(33.3)\end{array}$ & $\begin{array}{r}8.71 \\
(49.8)\end{array}$ & $\begin{array}{r}6 \\
(14.3)\end{array}$ & $\begin{array}{r}5.6 \\
(32.0)\end{array}$ \\
\hline Ramnagar & 88 & 14.35 & $\begin{array}{r}51 \\
(57.9)\end{array}$ & $\begin{array}{r}10.3 \\
(71.8)\end{array}$ & $\begin{array}{r}10 \\
(19.6)\end{array}$ & $\begin{array}{r}2.54 \\
(24.7)\end{array}$ & $\begin{array}{r}14 \\
(27.5)\end{array}$ & $\begin{array}{r}4.48 \\
(43.5)\end{array}$ \\
\hline Total & 223 & 83.65 & $\begin{array}{r}130 \\
(58.3)\end{array}$ & $\begin{array}{r}49.2 \\
(58.8)\end{array}$ & $\begin{array}{r}37 \\
(28.5)\end{array}$ & $\begin{array}{r}20.9 \\
(42.5)\end{array}$ & $\begin{array}{r}25 \\
(19.2)\end{array}$ & $\begin{array}{r}13.4 \\
(27.2)\end{array}$ \\
\hline
\end{tabular}

Source: Calculated from field survey data (Percentage in parenthesis)

Note: * Plots with 3 crops per year and repeated the same crops in a plot.

** Plots with crop cycle and many crops in a plot and crops are usually change in the successive year. 


\section{Crop Diversification}

Singh and Dhillon (1984) have found diversification in crop in India by developing of Crop Diversification Index (CDI). It is based on the principle that if the total cultivated area in a region is devoted wholly to one crop (i.e. specialization), the index value will be zero ( 0 ) and if it is evenly distributed among all crops (i.e. maximum diversification), the index value approaches one (1).

Table 9 shows that all index values are higher than 0.5 , and it seems closer to 1 which means that there is a great diversity in crops in the study area during the study period. However, it is also noticed that the crop diversity index has been increased in all study sites within the study period. It means that farmers were adopting crop diversification strategy on land management for more output from agricultural land.

Table 9: Crop diversification index (CDI)

\begin{tabular}{|l|r|r|r|r|}
\hline \multicolumn{1}{|c|}{ Study Sites } & $\begin{array}{c}\text { Index value for } \\
2005 / 06\end{array}$ & $\begin{array}{c}\text { Index value for } \\
2015 / 16\end{array}$ & Diversified parcels & Area (ha) \\
\hline Jahada & 0.62 & 0.71 & 5 & 3.3 \\
\hline Palhi & 0.62 & 0.64 & 6 & 5.6 \\
\hline Ramnagar & 0.68 & 0.76 & 14 & 4.5 \\
\hline
\end{tabular}

Source: Compiled from field survey data

During the FGD and KII, participants shared that farmers have been utilizing their cropping land with other crops when they get loss in the production of major crops like paddy, wheat and maize continually since two-three years. The research found that 19.2 percent (13.5 percent in Jahada, 14.3 percent in Palhi and 27.5 percent in Ramnagar) of the total crop land in the study area has been used for crop diversification (Figure 5). That is, they have been changing their crops, usually potato, vegetables, oilseeds and pulses with wheat in previous wheat monoculture area in the study sites. This type of practice is also found in the Bishnupura VDC of Rupandehi district (DoA, 2011), where farmers had practiced substitute of crops or crop rotation practice when the farmers got loss in production. 


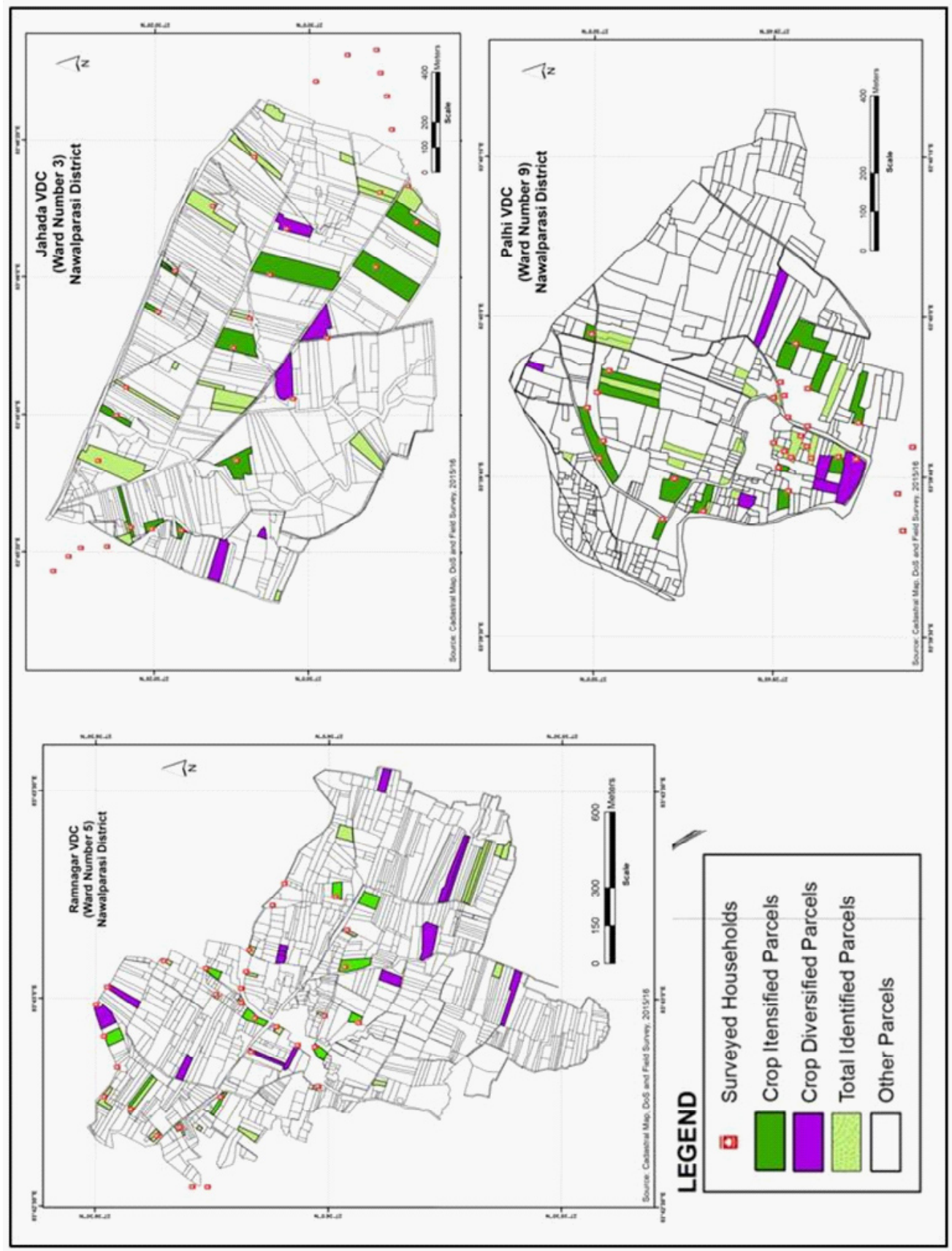

Figure 5: Crop intensification/diversification conditions by parcels 


\section{Conclusion}

Agricultural land management is the useof available inputs such as, use of labour and machineries, manure, improved seeds, chemical fertilizers, pesticides, and irrigation facilities to obtain more production. For the maximization of production, use of labour, manure, chemical fertilizers and pesticides in major crops, land intensification and crop diversification for agricultural land management practices are found to be conduct in the study sites. It has been found that the increasing trend of use of manure in the study sites is reciprocal to production. Beside, intensification and crop diversification practices are commonly observed that intend to meet the increasing demand of food. Farmers have used the cultivate land from one or two crop to three and more crop during the study period in the study sites. The farmers are found to have been using more intensive farming in the parcels close to residence/house than those who stay farther from the location. Similarly, farmers are reported to have been adopting crop diversification strategy on land management for maximum benefit of land in the study area.

\section{Reference}

Bhandari, P. B., and Ghimire, D. (2016).Rural agricultural change and individual outmigration. Rural Sociology, 81(4), 572-600. doi:10.1111/ruso.12106.

Bhat, M. M. (2013). Agricultural land use pattern in Pulwama district of Kashmir valley. International Journal of Economics, Business and Finance, 1(5), 80- 93.

Burgess, P. J., \& Morris, J. (2009). Agricultural technology and land use futures: The UK case. Land Use Policy,26, S222-S229.

Carswell, G. (2002). Farmers and fallowing: Agricultural change in Kigezi district, Uganda. The Geographical Journal, 168(2), 130-140.

Dahal, B. M., Nyborg, I., Sitaula, B. K., \& Bajracharya, R. M. (2009). Agricultural intensification: Food insecurity to income security in a mid-hill watershed of Nepal. International Journal of Agricultural Sustainability, 7(4), 249-260.

Dhakal, B. N. (2018). Agricultural land use change in Nawalparasi district: A temporal and spatial analysis. PhD dissertation (Final draft submitted to Dean Office for external examination), Faculty of Humanities and Social Sciences, Tribhuvan University, Kathmandu, Nepal.

DoA. (2011). Study on farm management practices in selected district of Nepal. Lalitpur: Government of Nepal, Ministry of Agriculture \& Cooperatives, Department of Agriculture. 
Khanal, N. R. (2002). Land use land cover dynamics in the Himalaya: A case study of the Madi watershed, western development region, Nepal. Unpublished doctoral dissertation, Tribhuvan University, Kathmandu.

Kristensen, S. P. (1999). Agricultural land use and landscape changes in Rostrup, Denmark: Process of intensification and extensification. Landscape and Urban Planning, 46(1), 117-123.

MacLeod, C. J. \& Moller, H. (2006). Intensification and diversification of New Zealand agriculture since 1960: An evaluation of current indicators of land use change. Agriculture, Ecosystems and Environment, 115, 201-218.

Miheretu, B. A., \& Yimer, A. A. (2017). Determinants of farmers' adoption of land management practices in Gelana sub watershed of Northern highlands of Ethiopia. Ecological Processes, 6, 19. doi:10.1186/s13717-017-0085-5

MoAD (2016). Production cost \& marketing of cereal, cash, vegetable and industrial crops in Nepal, 2015/16. Kathmandu: Government of Nepal, Ministry of Agriculture Development, Department of Agriculture.

MoFALD (2017). Gaunpalika tatha Nagarpalika ko sanchhipta parichaya (in Nepali), Kathmandu: Government of Nepal, Ministry of Federal Affairs and Local Development.

MoFALD(2015). Jilla, Nagarpalika tatha Gaunbikash Samitiharuko sanchhipta bibaran pustika (in Nepali), Kathmandu: Government of Nepal, Ministry of Federal Affairs and Local Development.

Nepal, R., \& Thapa, G. B. (2009). Determinants of agricultural commercialization and mechanization in the hinterland of a city in Nepal. Applied Geography, 29, 377-389.

Paudyal, N. P. (2010). Role of irrigation in crop production and productivity: A comparative study of tube well and canal irrigation in Shreepur VDC of Kanchanpur District. The Geographical Journal of Nepal, 8, 53-62.

Poudel, G. S. (2002). Coping with land scarcity: Farmers' changing land use and management practice in two mountain watersheds of Nepal. Norwegian Journal of Geography, 56, 21-31.

Semwal, R. L., Nautiyal, S., Sen, K. K., Rana, U., Maikhuri, R. K., Rao, K. S., \& Saxena, K. G. (2004). Patterns and ecological implications of agricultural land use changes: A case study from Central Himalaya, India. Agriculture, Ecosystems and Environment, 102, 81-92. 
Sen, K. K., Semwal, R. L., Rana, U., Nautiyal, S. R., Maikhuri, K., Rao, K. S., \& Saxena, K. G. (2002). Patterns and implications of land use and land cover change, a case study in Pranmati Watershed, Garhwal Himalaya, India. Mountain Research and Development, 22 (1), 56-62.

Singh, J., \& Dhillon, S. S.(1984). Agricultural geography (pp. 209-244). New Delhi: Tata McGraw-Hill Publishing Company Limited.

Thapa, G. B., \& Yila, O. M. (2012).Farmers' land management practices and status of agricultural land in the Jos plateau, Nigeria. Land Degradation and Development, 23, 263-277.

Wu, J., Cheng, X., Xiao, H., Wang, H., Yang, L., \& Ellis, E. C. (2009). Agricultural landscape change in China's Yangtze delta (1942-2002): A case study. Agriculture, Ecosystems and Environment, 129, 523-533. 